\title{
ABOUT THE PRECISION OF THE LIQUID DOSER OF SLIT TYPE WITH WAVEFORMATED SURFACES
}

\author{
S.G. Nekrasov, nekrasovsg@susu.ru \\ South Ural State University, Chelyabinsk, Russian Federation
}

\begin{abstract}
The device is used as an executive element of systems of biomedical assignment and can is used as the precision doser of liquid. The doser represents the slot-hole camera with waveformated surfaces. In contrast to the devices of peristaltic type with an elastic hose the considered device has no essential restrictions of downstream pressure and doesn't contaminate the transported liquid.

In work the current of an incompressible fluid in a flat slot of infinite width is considered. Two cases of creation of the waveformated movement in an operating slot are analyzed: the movement in the form of the running wave and the movement in the form of the fluctuations modulated by the running wave. In the latter case, it is possible to implement, irrespective of the required frequency of the running wave, rather big resonant fluctuations of elements of the piezoelectric transducer. It, in turn, allows to receive, at high resonance frequency, a small-size design of the piezoelectric transducer. At the same time in its operating slot there is a longitudinal movement of waves of resonant vibration, and the pressure differentials corresponding to them.

Flow of an incompressible liquid in a flat gap is considered. The equation of Reynolds is used for the description of driving of the fluid environment, the decision concerning pressure is brought to analytical expressions or quadratures. The lubricant flow rate and difference of pressure is defined on working length in an explicit form. Increase in pressure and expense in thin layers of an incompressible fluid with growth of amplitude and frequency of wave movements is shown. It is noted that it is slightly less magnitude of pressure differentials and expenses in layers with the fluctuations modulated by the running wave, than in layers with the running wave. These results are assessment from above and can be significantly less at emergence of cavitation in liquid.

The analytical results received in work allowed to consider also questions of ensuring accuracy of operation of the doser in the different modes of its operation. It is shown that the largest accuracy of dispensing is reached when transporting liquid from a vessel in a vessel with identical pressure or in case of overlapping of a gap crests of a running wave.
\end{abstract}

Keywords: doser, slot, running wave, amplitude, Reynolds's equation, incompressible fluid, analytical decision, lubricant flow rate, pressure, accuracy, relative error.

\section{Introduction}

Now in instrument making as the executive elements of management systems, etc. peristaltic (hose) pressurizer, doser and transporters are widely used [1,2], the principle of which is based waveformated motion of the working body (the hose) in which the transmittable material comes into contact only with the inner surface of the hose and not with any moving parts. They have unique properties, as suitable for transportation of corrosive, abrasive and other products with solid particles and liquids sensitive to hydraulic agitation, so the task of improving these device is relevant.

In Fig. 1 and 2 examples of the devices of transportation of peristaltic type developed [1] the Longer Precision Pump Co company are presented. In Fig. 1 device of biomedical appointment for dispensing of liquid is presented which is supplied with specially developed syringes and the valve and allows to minimize significantly mistakes in a pipetting. In Fig. 2 the transportation device for a hemodialysis with the brushless direct current motor ensuring stable functioning with low noise level which has the small size and is suitable for the OEM equipment and tools is presented.

It should be noted that the inevitable wear of a hose at his deformations complicates use of the device in some sensitive areas, for example, chemical since products of wear of a hose can pollute eventually liquid. Besides, pressure at the exit of the device is limited to strength properties of an elastic polymeric hose and can't be sufficient in the majority of applications. There are also restrictions on temperature of the pumped liquid. 


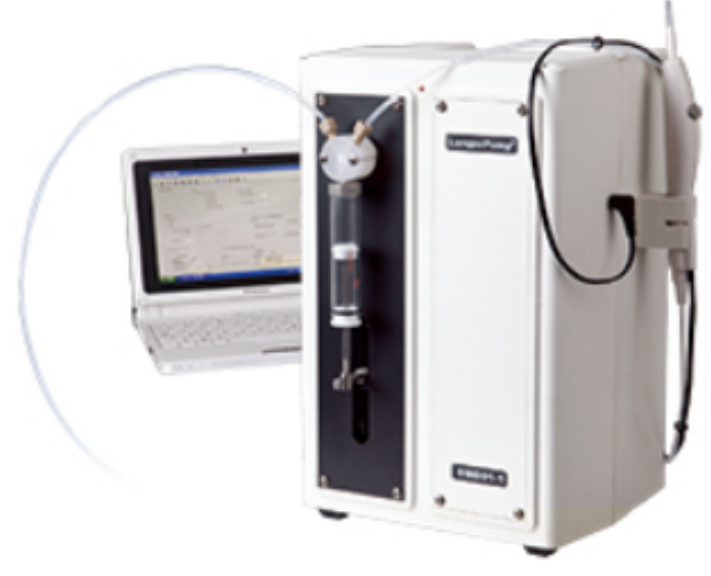

Fig. 1. Precision doser of biomedical appointment

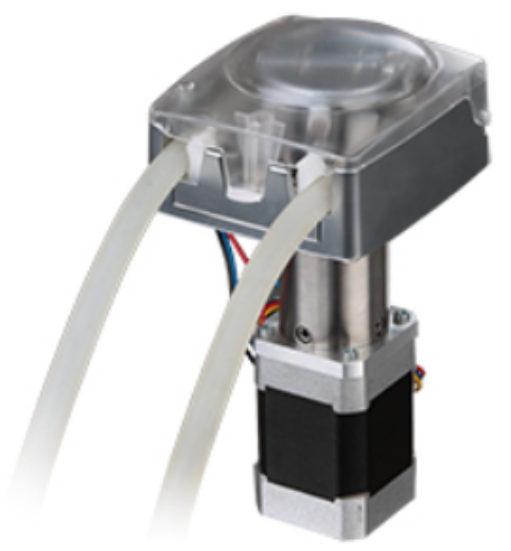

Fig. 2. The liquid conveyor for a hemodialysis

Obviously, if you replace the flexible hose of an elastic cylinder made of metal and provide waveformated motion of its surface, the working body of the pump will be almost perpetual, and the magnitude of the output pressure will be limited to only the design and operational features of the engine, which in this case must be performed on the basis of piezoelectric materials. Small amplitude of oscillations of the working surface of the piezoelectric motor (vibration motor) defines the small value of gap, which is implemented waveformated motion. It superimposes more strict requirements on composition and properties of the transferred liquids and enters natural restriction for productivity for one cycle of oscillations which, however, can be compensated for the score of the appropriate increase in operating frequency.

We will study the main characteristics of a liquid gap with the waveformated motion of surfaces which are mathematically described by functions like the running wave, we will consider at the same time not only surfaces with the running wave, but also with the fluctuations modulated by the running wave that provides a number of technical advantages at realization of the device.

\section{The increase in pressure and flow in a thin layer of incompressible fluid}

To estimate the main characteristic of the doser - dosing accuracy - it is necessary to have transformation function [3], i.e. dependence between input and output value. For the solution of this task we will consider a task about the planar flow of viscous incompressible fluid in a thin layer of infinite width, enclosed between a flat moving surface 1 (Fig. 3) immobile and 2, forming a longitudinal running wave in the direction of the coordinates $\mathrm{x}$. We will apply Reynolds's equation in form with pressure [4, 5] to the description of the movement of the environment.

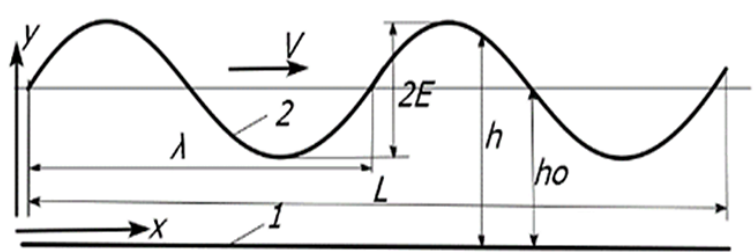

Fig. 3. The gap with waveformated surface

$$
\frac{\partial h_{i}}{\partial t}-(1 / 12 \mu) \frac{\partial}{\partial \bar{x}}\left(h_{i}^{3} \frac{\partial \mathscr{P}}{\partial \bar{x}}\right)=0,
$$

where $\mathscr{P}$ - instant value of pressure in a layer, $\mathscr{P}_{0}$ - environment pressure.

The gap function will describe the following two expressions:

$$
h_{1}=h_{0}\left\{1+E_{0} \cos [\omega(t-\bar{x} / V)]\right\}, h_{2}=h_{0}\left\{1+E_{0} \cos [\omega(t-\bar{x} / V)] \cos v t\right\},
$$

in which $h_{0}$ is the mean value of gap (Fig. 3), $E_{0}=E / h_{0}$ is the dimensionless amplitude of the running wave, $\omega=2 \pi \bar{\omega}$ is the circular frequency of the moving wave; $v$ - circular frequency normal gap fluctuations $(\omega \ll v), V=\lambda \bar{v}-$ the velocity of the running wave, $\lambda$ is the wavelength. Gap function $h_{1}(2)$ describes the process of kinematic excitation of the liquid layer waveformated motion of the running wave type, and the function $h_{2}$ - layer with the fluctuations modulated by the running wave, $i=1,2$ (the author proposed invention the reference node with the wave of the form $h_{2}$ [6], which facilitates the task of designing). 


\section{Краткие сообщения}

Proceed to dimensionless parameters $[7,8] P=\mathscr{P} / \mathscr{P}_{0}, H_{i}=h_{i} / h_{0}, \tau=\bar{\omega} t, x=\bar{x} / \lambda$, which allows to obtain the following equation for the pressure distribution:

$$
\Lambda_{\omega} \frac{\partial H_{i}}{\partial \tau}=\frac{\partial}{\partial x}\left(H_{i}^{3} \frac{\partial P}{\partial x}\right)
$$

where $H_{1}=1+E_{0} \cos 2 \pi(\tau-x), H_{2}=1+E_{0} \cos 2 \pi(\tau-x) \cos (2 \pi \tau \nu / \omega), \Lambda_{\omega}=\frac{12 \mu \omega \lambda^{2}}{\mathscr{P}_{0} h_{0}^{2}}$.

Boundary conditions for pressure:

$P=1$, at $x=0 ; P=P_{n}$, at $x=\bar{L}$

and $\bar{L}=L / \lambda-$ dimensionless length of the layer.

The solution we will make for the layer thickness, defined by the expression $h_{2}$ (2), and the result for the layer $h_{1}$ will receive in the form of a special case, assuming the frequency $v \rightarrow 0$. We will integrate with $x$ equation (3) and substitute the result into the expression for the time derivative and the dimensionless gap $\mathrm{H}_{2}$ :

$$
H_{2}^{3} \frac{\partial P}{\partial x}=\Lambda_{\omega}\left\{E_{0} \sin 2 \pi(\tau+x) \cos (2 \pi \tau \nu / \omega)-(2 \pi \nu / \omega) E_{0} \cos 2 \pi(\tau+x) \sin (2 \pi \tau \nu / \omega)\right\}-C_{2} .
$$

Here $C_{2}$ is a constant flow rate, defines the average of fluctuations in the mass flow rate of the fluid

$$
\bar{G}=k_{g} \int_{0}^{1} C_{2} d \tau
$$

To obtain expressions for the pressure distribution we will integrate with $x$ the expression (5):

$$
\begin{aligned}
& P=\frac{\Lambda_{\omega} E_{0}}{2 \pi}\left\{\cos (2 \pi \tau \nu / \omega)\left[-A_{1}(\tau)+A_{1}(\tau-x)\right]+(\nu / \omega) \sin (2 \pi \tau / \omega)\left[-A_{2}(\tau)+A_{2}(\tau-x)\right]\right\}- \\
& -C_{2} /(2 \pi)[-B(\tau)+B(\tau-x)]+C_{1},
\end{aligned}
$$

in which the $A_{1}, A_{2}$ and $B$ parameters are similar to the parameters received in work [9]. The constant $C_{1}$ and $C_{2}$ are determined from boundary conditions for pressure (4):

$$
\begin{aligned}
& C_{1}=1, \\
& C_{2}=2 \pi\left(P_{n}-1\right)-E_{0} \Lambda_{\omega}\left\{\cos (2 \pi \tau \nu / \omega)\left[A_{1}(\tau)-A_{1}(\tau-L)\right]+\right. \\
& \left.+\nu / \omega \cdot \sin (2 \pi \tau \nu / \omega)\left[-A_{2}(\tau)+A_{2}(\tau-L)\right]\right\} /[B(\tau)-B(\tau-L)] .
\end{aligned}
$$

We consider the case when the length of the layer is divisible to the length of the running wave. We assume that $l=n \lambda$ and so $L=n, n=1,2,3, \ldots$, and then, after some transformations, we obtain the average flow rate over the period of a running wave

$$
\bar{G}_{2}=\frac{k_{g} \omega}{2 \pi \nu}\left[3 E_{0}^{2} J_{1}\left(E_{0}\right) \Lambda_{\omega}-\frac{2}{n} J_{2}\left(E_{0}\right)\left(P_{n}-1\right)\right]=\bar{G}_{2 \omega}+\bar{G}_{2 p},
$$

where $J_{1}=\int_{0}^{2 \pi} \frac{\cos ^{2}(z) d z}{2+E_{0}^{2} \cos ^{2}(z)}, J_{2}=\int_{0}^{2 \pi} \frac{\sqrt{\left(1-E_{0}^{2} \cos ^{2}(z)\right)}}{2+E_{0}^{2} \cos ^{2}(z)} d z, \quad k_{g}=\frac{\rho \mathscr{P}_{0} h_{0}^{3}}{12 \mu}$.

To estimate the magnitude of fluid flow caused by action of moving wave vibration, we assume $P_{n}=1$, then from (9) it follows

$$
\bar{G}_{2 \omega}=\frac{k_{g} \omega}{2 \pi \nu} 3 E_{0}^{2} J_{1} \Lambda_{\omega} \text {. }
$$

We can assess the possibility of medium with vibrations modulated running wave as compression, we need to put $\bar{G}_{2}=0$, then from (9) we can find the magnitude of the pressure drop:

$$
\Delta P_{2}=P_{n}-1=3 E_{0}^{2} \Lambda_{\omega} n J_{1} / 2 J_{2} \text {. }
$$

Similar results for the layer with the moving wave can be obtained by removing high-frequency filling from the resulting solution $(v / \omega \rightarrow 0)$ : 


$$
\Delta P_{1}=P_{n}-1=\frac{3 E_{0}^{2} \Lambda_{\omega} n}{2\left(1-E_{0}^{2}\right)\left(1-E_{0}^{2}\right)^{\frac{1}{2}}}, \bar{G}_{1}=\bar{G}_{1 \omega}+\bar{G}_{1 P},
$$

where

$$
\bar{G}_{1 \omega}=k_{g} \frac{3 E_{0}^{2}}{2+E_{0}^{2}} \Lambda_{\omega}, \bar{G}_{1 P}=-k_{g} \frac{2 \sqrt{1-E_{0}^{2}}\left(1-E_{0}^{2}\right)}{2+E_{0}^{2}}\left(P_{n}-1\right) .
$$

\section{Some results of calculations}

Judging by the fluid flow, the medium with a running wave significantly exceed the capability of the medium with a moving wave in the presence of vibrations, and with the growth of $v / \omega$ it becomes more remarkable (Fig. 2). However, it is necessary to consider, that in the design realizing the modulated fluctuations [6], it is possible to set independently the resonant frequency of fluctuations of an active surface and frequency of the running wave that significantly facilitates physical realization of the device.

The dependence for lubricant flow rate $\bar{G}_{2 \omega}$ is presented on Fig. 4 and indicates the linear growth of flow rate with growth of frequency parameter $\Lambda_{\omega}$. The dependence for flow rate $\bar{G}_{1 \omega}$ isn't provided in a graphic form because of the evidence, for example, at $E_{0}=1$ quantity $\bar{G}_{1 \omega}=k_{g} \Lambda_{\omega}$. The expenditure $\bar{G}_{\omega}$ doesn't depend on viscosity and, therefore, such mechanism of transfer of the incompressible liquid environment isn't connected with the relative movement of its layers.

On the contrary, flow rate $\bar{G}_{p}$ is inversely proportional dynamic viscosity of the liquid environment, and increase in amplitude of vibration leads to increase $\Delta P$, reduction $\bar{G}_{p}$, that can be regarded as increase in effective viscosity [10] of a layer.

The dependence of pressure differentials $\Delta P_{2}$ (Fig. 5) has linear dependence on parameter $\Lambda_{\omega}$ and doesn't depend on the relation $v / \omega$. The average pressure differentials, generated by a layer in lack of vibration, is slightly more $\left(\Delta P_{1}>\Delta P_{2}\right)$, and this ratio will be carried out irrespective of relation size $v / \omega$ when performing a condition $v / \omega>2$.

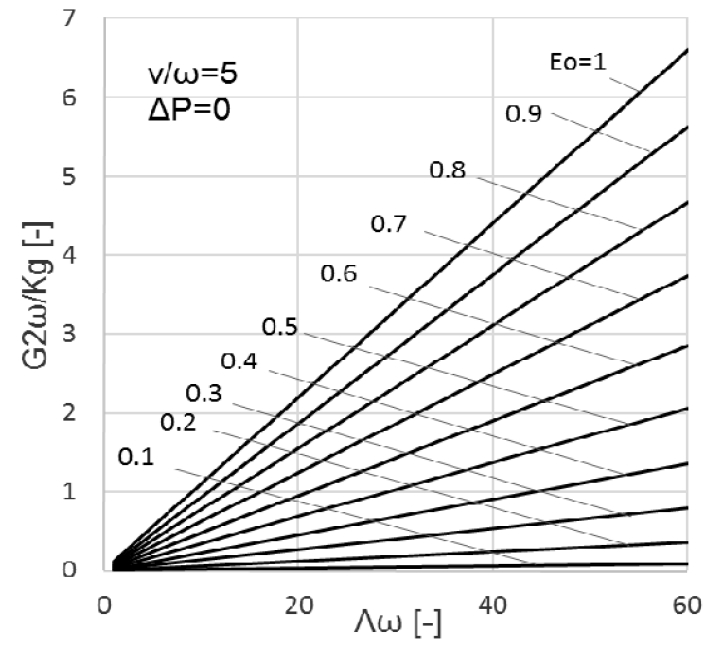

Fig. 4. Flow rate, average during fluctuations, in a layer with the modulated running wave

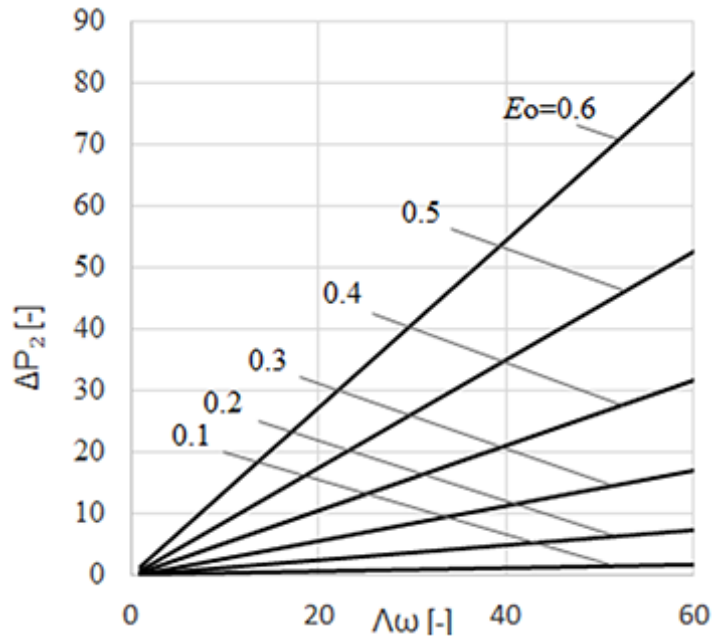

Fig. 5. Pressure differential a layer with the modulated running wave

Use of a layer with the running wave as the doser of liquid it is possible, because from the expressions of flow rate we see that the flow rate are linearly dependent on the frequency parameter $\Lambda_{\omega}$ and, therefore, increasing the frequency of the running wave, theoretically, arbitrarily large flow rate and pressure differentials can be obtained. There are also other ways of creation of the flow rate [11] on the basis of a layer of compressible fluid with vibration. However, this option has no competitors on efficiency for the compressed [12] and incompressible liquid. 


\section{Краткие сообщения}

\section{Operational accuracy of the doser}

In operation of the doser of an error, connected with instability of parameters of the generator which provides a multiphase power supply of a piezoelectric engine, are the most essential. They are, in fact, entrance if to consider the doser as the converter of input electric parameters in mechanical. Distinguish long-term and fast instability which can be connected from a different look by the noise induced in the electromagnetic way in different cascades of the multichannel generator of sine wave voltage of a power supply or fluctuations of mains voltage, or failures of system of an auto-adjust of frequency, etc. Fast instability are the most essential since time of their existence usually corresponds to typical operating time of the doser, and they come down, generally, to change of frequency of $\omega$ and amplitude of supply voltage that in proportion leads to change of frequency (frequency parameter $\Lambda_{\omega}$ ) and amplitudes of $E_{0}$ of fluctuations of the running wave.

We will consider at first the accuracy of a task of pressure in the closed camera. We use for such linear assessment, the expressions received in an explicit form for difference of pressure. We will execute two, known in theory of errors [13], auxiliary operations: we take the logarithm expression for $\Delta P_{1}$ (16) (the line over symbols is hereinafter lowered) and then we differentiate it. As a result we find:

$$
\frac{d\left(\Delta P_{1}\right)}{\Delta P_{1}}=\frac{d\left(\Lambda_{\omega}\right)}{\Lambda_{\omega}}+2 \frac{d E_{0}}{E_{0}}+3 \frac{d E_{0}}{E_{0}} \frac{E_{0}^{2}}{1-E_{0}^{2}} .
$$

From there, their relative error from a task of pressure $\delta\left(\Delta P_{1}\right)$ will be

$$
\delta\left(\Delta P_{1}\right)_{n p}=\delta\left(\Lambda_{\omega}\right)+\delta E_{0}\left(2+3 \frac{E_{0}^{2}}{1-E_{0}^{2}}\right),
$$

where

$$
\delta\left(\Delta P_{1}\right)=\frac{\Delta\left(\Delta P_{1}\right)}{\Delta P_{1}} ; \delta\left(\Lambda_{\omega}\right)=\frac{\Delta\left(\Lambda_{\omega}\right)}{\Lambda_{\omega}} ; \delta\left(E_{0}\right)=\frac{\Delta\left(E_{0}\right)}{E_{0}},
$$

$\Delta\left(\Delta P_{1}\right), \Delta\left(\Lambda_{\omega}\right), \Delta\left(E_{0}\right)$ - relative and absolute errors of a task of pressure difference, frequency and amplitude of fluctuations respectively.

Mean square relative and absolute errors from task of pressure are equal:

$$
\begin{aligned}
& \delta\left(\Delta P_{1}\right)_{c k}=\sqrt{\delta\left(\Lambda_{\omega}\right)^{2}+\delta E_{0}{ }^{2}\left(2+3 \frac{E_{0}^{2}}{1-E_{0}^{2}}\right)^{2}}, \\
& \Delta\left(\Delta P_{1}\right)_{c k}=\sqrt{\delta\left(\Lambda_{\omega}\right)^{2}+\delta E_{0}{ }^{2}\left(2+3 \frac{E_{0}^{2}}{1-E_{0}^{2}}\right)^{2}} \frac{3 E_{0}^{2} \Lambda_{\omega} n}{2\left(1-E_{0}^{2}\right)\left(1-E_{0}^{2}\right)^{\frac{1}{2}}} .
\end{aligned}
$$

Having performed similar operations, we can find an error of a task of the lubricant flow rate $G_{1 \omega}$ depending on the frequency and amplitude of the running wave, and the flow rate $G_{1 P}$ directed opposite $G_{1 \omega}$ and depending on difference of pressure:

$$
\begin{aligned}
& \delta\left(G_{1 \omega}\right)_{n p}=\delta\left(\Lambda_{\omega}\right)+2 \delta\left(E_{0}\right)\left(1-2 \frac{E_{0}^{2}}{1+E_{0}^{2}}\right), \\
& \delta\left(G_{1 P}\right)_{n p}=\delta\left(E_{0}\right)\left(3 \frac{E_{0}^{2}}{1-E_{0}^{2}}+2 \frac{E_{0}^{2}}{2+E_{0}^{2}}\right) .
\end{aligned}
$$

In Fig. 6a relative limiting $\delta\left(\Delta P_{1}\right)_{n p}$ and mean square relative $\delta\left(\Delta P_{1}\right)_{c k}$ errors of a task of pressure are presented, and the mean square error (a curve 2) usually is considered more reliable. It is obvious, that with growth of amplitude of $E_{0}$ the relative error of a task of pressure, as well as pressure, grows, striving at $E_{0} \rightarrow 1$ for infinity.

In Fig. $6 \mathrm{~b}$ relative errors of a lubricant flow rate are shown. It is visible that the relative error of a flow rate of $G_{1 \omega}$ connected only with action of the running wave has the minimum size. The error of 
frequency $\delta\left(\Lambda_{\omega}\right)$ enters a relative error $G_{1 \omega}$ of an additional variable and has no features. The error of the return flow rate of $G_{1 P}$ perceives all features of an error of pressure differential $\Delta P_{1}$ and also aims at infinity at $E_{0} \rightarrow 1$. Diagrams of the relative errors make purely technical sense here and illustrate, in fact, the intermediate calculated data.

Several other result is visible on schedules of absolute errors in Fig. 7. It is visible that at value of the setting absolute errors of $\Delta\left(E_{0}\right)=0,01 E_{0}$ and $\Delta\left(\Lambda_{\omega}\right)=0,01 \Lambda_{\omega}$ the absolute error of $G_{1 \omega}$ practically doesn't exceed one cell in all range of dimensionless amplitude of $E_{0}$.

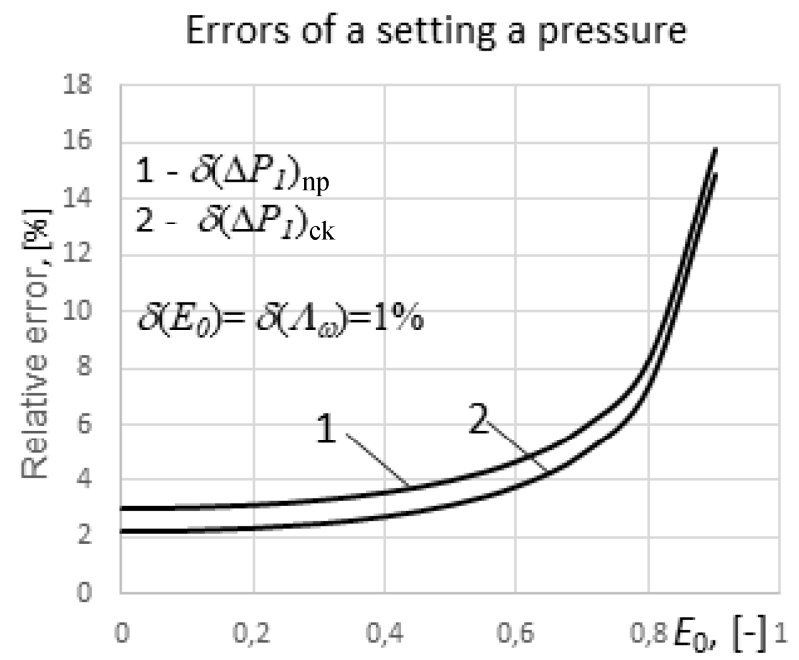

a)

\section{Errors of setting a flow rate}

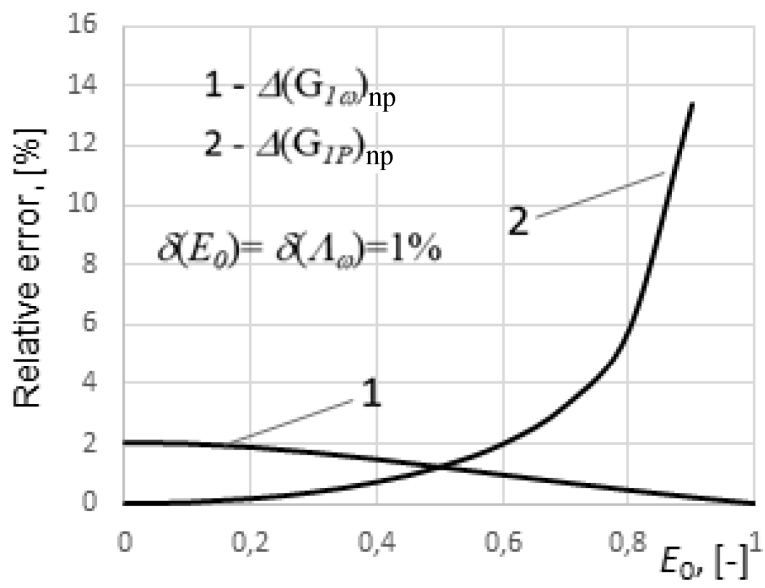

b)

Fig. 6. Relative errors of pressure (a) and flow rate (b)

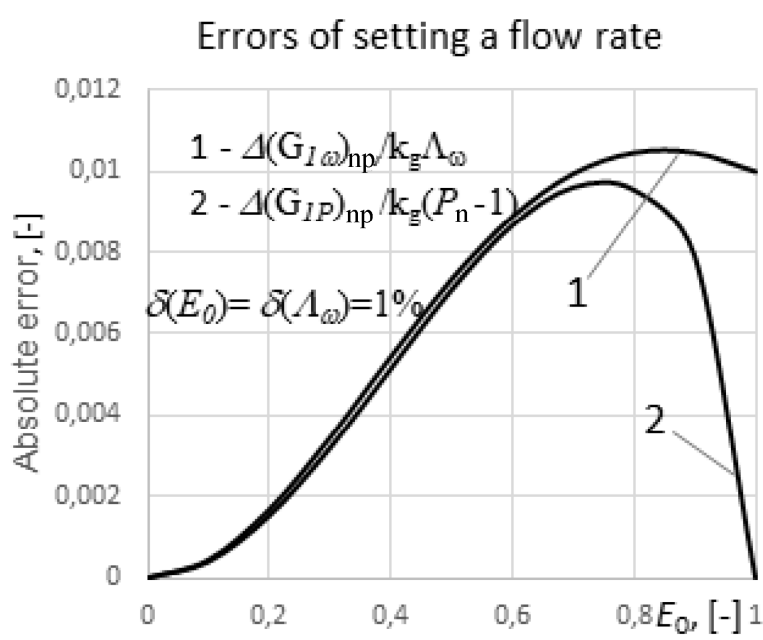

Fig. 7. Absolute errors of a lubricant flow rate

In the same conditions the absolute error of lubricant flow rate of $G_{1 P}$ also doesn't exceed one cell in all range of dimensionless amplitude of $E_{0}$, and for $E_{0} \rightarrow 1$ amplitudes, when on crests of the running wave there is a full blocking of a gap, the return flow rate and its absolute error tend to zero (a curve 2, Fig. 7). Maximum total absolute error of a flow rate doesn't exceed dimensionless size 0,02 at $E_{0}=0,8$. Here it is necessary to represent that though the relative error is much more often used in practice because of convenience, however, the essence (physics) of an error always contains in its absolute value [15].

\section{Conclusions}

The considered doser has no shortcomings of peristaltic devices with flexible polymeric hoses and allows to receive the no-wear working area of slot-hole type with theoretically beyond all bounds big 


\section{Краткие сообщения}

feed pressures of liquid. The largest accuracy of dosing is reached when transporting liquid from a vessel in a vessel with identical pressure and also in case of blocking of a gap at $E_{0} \rightarrow 1$.

\section{Referenses}

1. Available at: http://longerpump.com/ (accessed 15.05.2018).

2. Available at http://www.watson-marlow.com/ (accessed 18.05.2018).

3. Zhukov V.K. Teoriya pogreshnostey tekhnicheskikh izmereniy [The Theory of Errors of Technical Measurements]. Tomsk, Tomsk Polytechnic Institute Publ., 2009. 180 p.

4. Loytsyanskiy L.G. Mekhanika zhidkosti i gaza [Mechanics of Liquid and Gas]. Moscow, Nauka Publ., 1973. 741 p.

5. Constantinesku V.N. Gas Lubrication. The American Society of Mechanical Engineers, New York, 1969. 709 p.

6. Nekrasov S.G., et al. Vibronesushaya gazovaya opora. [The Vibrobearing Gas Support]. Author's Certificate (SU), no. 1225310 A, F 16 C 17/02, 32/00; publ. 16.07.84, Bul. no. 31.7 p.

7. Moderau P.W. [The Effect of Increased Environment in the Gaps with a Running Vave]. Trudy vsesoyuznoi konferentsii po gazovym podshipnikam turbomashine. [Proc. of All-Union Conference on Gas Bearings of Turbomachines]. Kazan, 1975, pp. 15-19. (in Russ.)

8. Nekrasov S.G., Pashnina N.A. The Profiling Effect on the Characteristics of Gas Flow in Fine Vibrating Clearances. Journal of Friction and Wear, 2010, vol. 31, no 3, pp. 171-179.

9. Nekrasov, S.G. To the Projection of a Peristaltic Slit Pump. Procedia Engineering, 2016, vol. 150, pp. 506-513. DOI: 10.1016/j.proeng.2016.07.030

10. Blekhman I.I. $O$ "vibratsionnoy mechanike" $i$ vibratsionnoy technike. [About "Vibration Mechanics" and the Vibration Technician]. Moscow, Nauka Publ., 1988. 208 p.

11. Nekrasov, S.G., et al. Ultrazvukovoy gazoviy compressor $i$ orositel' na ego osnove. [The Ultrasonic Gas Compressor and the Sprinkler on its Basis]. Patent RF, no. 2121612; publ. 10.11.1998, Bul. no. $31.9 \mathrm{p}$.

12. Nekrasov S.G. Hydrodynamic Seal on the Basis of a Cylindrical Layer of the Compressible Fluid with a Running Wave. Procedia Engineering, 2016, vol. 150, pp. 514-519. DOI: 10.1016/j.proeng.2016.07.032

13. Toytbert P.A. Oshovy tochnosty rezul'tatov izmereniy [Bases of Accuracy of Results of Measurements]. Moscow, Energoatomizdat Publ., 1988. 88 p.

14. Stepanov O.A. Osnovy teorii otsenivaniya s prilozheniyamy $k$ zadacham obrabotky navigatsionnoy informatsii [Bases of the Theory of Estimation with Apps to Problems of Processing of Navigation Information]. St. Petersburg, GSC RF Central Research Institute "Elektropribor" Publ., 2009. 496 p.

15. Gutkin M.B., Mishustin V.I., Chistyakov Yu.A. [The Metrological Backup for Measurements of the Flow Rate and Volume of Liquids and Gases in Russia]. Measurement Techniques, 2010, no. 3, pp. 30-34. (in Russ.)

Received 28 May 2018 


\title{
О ТОЧНОСТИ ДОЗАТОРА ЖИДКОСТИ ЩЕЛЕВОГО ТИПА С ВОЛНООБРАЗУЮЩИМИ ПОВЕРХНОСТЯМИ
}

\author{
С.Г. Некрасов \\ Южно-Уральский государственный университет, г. Челябинск, Россия
}

\begin{abstract}
Устройство применяется в качестве исполнительного элемента систем биомедицинского назначения и может использоваться в качестве прецизионного дозатора жидкости. Дозатор представляет собой плоскую щелевую камеру с волнообразующими поверхностями. В отличие от обычных устройств перистальтического типа с рабочим органом на основе эластичного шланга рассматриваемое устройство не имеет существенных ограничений на величину выходных давлений и не загрязняет транспортируемую жидкость.

В работе рассматривается течение несжимаемой жидкости в плоской щели бесконечной ширины. Анализируются два случая создания волнообразующего движения в рабочем зазоре: движение в виде бегущей волны и движение в виде колебаний, модулированных бегущей волной. В последнем случае удается независимо от требуемой частоты бегущей волны реализовать сравнительно большие резонансные колебания элементов пьезоактивного преобразователя. Это, в свою очередь, позволяет на достаточно высокой резонансной частоте получить малогабаритную конструкцию пьезоактивного преобразователя, в рабочем зазоре которого происходит продольное движение как волн резонансной вибрации, так и соответствующих им перепадов давлений.

Для описания движения жидкой среды использовано уравнение Рейнольдса, решение которого относительно давления доведено до аналитических выражений или квадратур. В частности, определен расход и перепад давлений на рабочей длине в явном виде. Показано увеличение давлений и расхода в тонких слоях несжимаемой жидкости с ростом амплитуды и частоты волновых движений. Отмечается, что величины генерируемых таким образом перепадов давлений и расходов в слоях с модулированными бегущей волной колебаниями несколько меньше, чем в слоях с бегущей волной. Данные результаты являются оценкой сверху и могут быть существенно меньше при появлении кавитации в жидкости.

Полученные в работе аналитические результаты позволили также рассмотреть вопросы обеспечения точности работы дозатора в различных режимах его эксплуатации. Получены аналитические выражения для погрешностей, показано, что наибольшая точность дозирования достигается при транспортировке жидкости из сосуда в сосуд с одинаковыми давлениями или в случае перекрытия зазора гребнями бегущей волны.

Ключевые слова: дозатор, щель, бегущая волна, амплитуда, уравнение Рейнольдса, несжимаемая жидкость, аналитическое решение, расход, давление, точность, относительная погрешность.
\end{abstract}

\section{Литература}

1. http://longerpump.com/ (дата обращения: 15.05.2018).

2. Available at http://www.watson-marlow.com/ (дата обращения: 18.05.2018).

3. Жуков, В.К. Теория погрешностей технических измерений / В.К. Жуков. - Томск: Изд-во Томск. политехн. ин-та, 2009. - 180 с.

4. Лойиянский, Л.Г. Механика жидкости и газа / Л.Г. Лойиянский. - М.: Наука, 1973. - 741 c.

5. Constantinesku, V.N. Gas Lubrication / V.N. Constantinesku. - The American Society of Mechanical Engineers, New York, 1969. - 709 p.

6. А. с. (СССР) 1225310 А, F 16 C 17/02, 32/00. Вибронесущая газовая опора / С.Г. Некрасов и др. -№ 53041732/05; опубл. 16.07.84, Бюл. № 22. -7 c.

7. Модерау, П.В. Эффект увеличения среды в зазорах с бегущей волной / П.В. Модерау // Труды Всесоюзной конференция по газовым подшипникам турбомашин. - Казань, 1975. - C. 15-19.

8. Nekrasov, S.G. The profiling effect on the characteristics of gas flow in fine vibrating clearances / S. G. Nekrasov, N.A. Pashnina // Journal of Friction and Wear. - 2010. - Vol. 31, no. 3. - P. 171-179. 


\section{Краткие сообщения}

9. Nekrasov, S.G. To the Projection of a Peristaltic Slit Pump / S.G. Nekrasov // Procedia Engineering. - 2016. - Vol. 150. - P. 506-513. DOI: 10.1016/j.proeng.2016.07.030

10. Блехман, И.И. О «вибрационной механике» и вибрационной технике / И.И. Блехман. - М.: Наука, 1988. - 208 c.

11. Пат. 2121612 РФ, МКИ В 05 В 17/04. Ультразвуковой газовый компрессор и ороситель на его основе / С.Г. Некрасов и др. - № 93032626/06; опубл. 10.11.98, Бюл. № 31. -9 c.

12. Nekrasov, S.G. Hydrodynamic Seal on the Basis of a Cylindrical Layer of the Compressible Fluid with a Running Wave / S.G. Nekrasov // Procedia Engineering. - 2016. - Vol. 150. - P. 514-519. DOI: 10.1016/j.proeng.2016.07.032

13. Тойтберт, П.А. Основы точности результатов измерений / П.А. Тойтберт. - М.: Энергоатомиздат, 1988. - $88 \mathrm{c}$.

14. Степанов, О.А. Основы теории оценивания с приложениями к задачам обработки навигащионной информации / О.А. Степанов. - СПб.: ГНЦ РФ ЦНИИ «Электроприбор», 2009. - 496 с.

15. Гуткин, М.Б. Метрологическое обеспечение измерений расхода и объема жидкостей и газов в России / М.Б. Гуткин, В.И. Мишустин, Ю.А. Чистяков // Измерительная техника. - 2010. № 3. - C. 30-34.

Некрасов Сергей Геннадьевич, д-р техн. наук, профессор кафедры информационно-измерительной техники, Южно-Уральский государственный университет, г. Челябинск; nekrasovsg@ susu.ru.

Поступила в редакцию 28 мая 2018 г.

\section{ОБРАЗЕЦ ЦИТИРОВАНИЯ}

Nekrasov, S.G. About the Precision of the Liquid Doser of Slit Type with Waveformated Surfaces / S.G. Nekrasov // Вестник ЮУрГУ. Серия «Компьютерные технологии, управление, радиоэлектроника». 2018. - T. 18, № 3. - C. 124-132. DOI: 10.14529/ctcr180313

\section{FOR CITATION}

Nekrasov S.G. About the Precision of the Liquid Doser of Slit Type with Waveformated Surfaces. Bulletin of the South Ural State University. Ser. Computer Technologies, Automatic Control, Radio Electronics, 2018, vol. 18 , no. 3 , pp. 124-132. DOI: $10.14529 /$ ctcr180313 